\title{
A Laboratory Evaluation for the Potential of Entomopathogenic Fungi against Tribolium castaneum (Herbst.) (Coleoptera: Tenebrionidae)
}

\author{
Muhammad Akmal 1,a, Shoaib Freed ${ }^{1, b, *}$, Muhammad Bilal,c, Muhammad Naeem Malik ${ }^{1, d}$ \\ ${ }^{1}$ Laboratory of Insect Microbiology and Biotechnology, Department of Entomology, Faculty of Agricultural Sciences and Technology, Pakistan
} *Corresponding author

\author{
A R T I C L E I N F O A B S T R A C T
}

Research Article

The red flour beetle is a very important primary insect pest of wheat worldwide. The experiments were performed to check the virulence of Beauveria bassiana and Isaria fumosorosea by insect dipping method on the adults and $2^{\text {nd }}$ instar of Tribolium castaneum. Conidia were taken from 15 days old fungi and subsequently four concentrations i.e., $2 \times 10^{8}, 3 \times 10^{8}, 4 \times 10^{8}$ and $5 \times 10^{8} \mathrm{spores} / \mathrm{ml}$

Received : 04/08/2017

Accepted : 20/05/2020 of both fungi were prepared in $0.05 \%$ Tween 80 solution. Minimum $12.5 \%$ and maximum $32.5 \%$ mortality of adult insects was recorded on $7^{\text {th }}$ day after the treatment at $2 \times 10^{8}$ and $5 \times 10^{8} \mathrm{spores} / \mathrm{ml}$ concentrations of $B$. bassiana, respectively while on larval stages, minimum $2.5 \%$ on $5^{\text {th }}$ day and maximum $80.0 \%$ mortality was observed on $7^{\text {th }}$ day post treatment of $B$. bassiana, respectively. On

Keywords: the other side, minimum 7.5 and maximum 22.5 mortality percentage was noted on $7^{\text {th }}$ day post Insect pathogenic fungi Red flour beetle Bioassay Immersion method Beauveria bassiana application of $I$. fumosorosea, respectively while on immatures minimum $5 \%$ on $6^{\text {th }}$ day and highest $70 \%$ mortality was noted on $7^{\text {th }}$ day post infection with $2 \times 10^{8}$ and $5 \times 10^{8}$ spores $/ \mathrm{ml}$ of $I$. fumosorosea, correspondingly. This study showed the effectiveness of insect pathogenic fungi against the important stored grain insect pest and proved to be a positive management strategy.

\section{Introduction}

Cereals are the utmost vital food crop for majority of the people of the world. Grain losses in their store houses because of insect damage hinders food accessibility for the people (Cogburn, 1980). Storage and maintenance of agricultural produce are very significant activities after harvesting. Substantial quantity of grains is being damaged after harvesting because of absence of adequate storing and processing services (Singh and Satapathy, 2003). Stored food products are infested by more than 670 insect pests, primarily consisting of beetles and lepidopterans thus causing quantitative and qualitative losses (Rajendran, 2002). Around $20-25 \%$ of grains are spoiled annually owing to insect pests (Rajashekar et al., 2010). In most of the developed countries like America, Canada, United Kingdom, Australia etc. there is zero thresholds for insectpests of stored products (White, 1995; Pheloung and Macbeth, 2002).

Tribolium castaneum (Herbst.) (Coleoptera: Tenebrionidae) is a diverse insect pest of stored products and plant based processed materials. Control of this insect relies mostly on the use of chemical insecticides and fumigants. Due to the constant use of insecticides it has developed resistance against different insecticides belonging to various groups (Haliscak and Beeman 1983; Beeman and Wright 1990; Zettler and Cuperus 1990; Arthur 1992).

The use of chemicals for the protection of grains is a very old practice. Insecticides have been in use for years for efficient control of insects (Salem et al., 2007). Themassive and indiscriminate use of insecticides however has resulted in increased resistance in insect pests along with hazardous residual effects (Norman, 2000, Philips and Throne, 2010). Moreover, their detrimental effects on nontarget species, handling hazards and the ecological consequences warrants further development of novel approaches in pest management (Salem et al., 2007; Mahdi and Rahman, 2008). Therefore, it is worthy to sort out natural supplements to insecticides which are readily available, cheap and less detrimental, having least mammalian toxicity (Talukder and Miyata, 2002: Udo, 2005; Phillips and Throne, 2010). 
Beauveria bassiana, Metarhizium anisopliae and Isaria fumosorosea an alternate to chemical insecticides are being used to manage a number of insects of stored grains (Murad et al., 2006). The conidia of fungus cause death of insect after penetration into its cuticle. Insect pathogenic fungi are naturally occurring organisms, safer to environment and less toxic to mammals (Cox and Wilking, 1996). $B$. bassiana and $I$. fumosorosea has proved its achievement against numerous stored products insects in laboratory and field conditions (Hidalgo et al., 1998; Smith et al., 1998, Rice and Cogburn, 1999; Bourassa et al., 2001; Moore et al., 2000; Dal-Bello et al., 2001; Padin et al., 2002; Stathers, 2002; Wakefield et al., 2002; Akbar et al., 2004) and used as registered food protectants in America (Moore et al., 2000). It is also stated that B. bassiana is used to manage $T$. castaneum, Sitophilus oryzae (L.) and Rhyzopertha dominica (Rice and Cogburn, 1999; Padin et al., 2002). The current research was carried out to investigate the efficacy of $B$. bassiana and I. fumosorosea against $T$. castaneum on both adult and immature stages.

\section{Materials and Methods}

Tribolium castaneum were raised on sound wheat in jars $(6 \times 10 \mathrm{~cm})$ under rearing conditions of $25 \pm 5^{\circ} \mathrm{C}, 75 \pm$ 5\% R. H. and 16: $8 \mathrm{~h} \mathrm{~L}$ : D. The jars were covered with cloth for aeration. Eclosed adults and $2^{\text {nd }}$ instar grubs were used in experiments. B. bassiana and I. fumosorosea were obtained from Insect Microbiology lab at Department of Entomology, Bahauddin Zakariya University and grown for two weeks on Potato Dextrose Agar (made from natural ingredients in the lab). Conidia were scrapped from 15 days old fungal plates and four concentrations i.e., $2 \times 10^{8}, 3 \times 10^{8}$, $4 \times 10^{8}$ and $5 \times 10^{8}$ of each fungus were made in $0.05 \%$ Tween 80 solution by serially diluting the stock solution while insects were treated by dipping method.

Ten adults and immatures of $T$. castaneum per replication were treated with fungi having strengths of $\left(2 \times 10^{8}, 3 \times 10^{8}, 4 \times 10^{8}\right.$ and $5 \times 10^{8}$ spores $\left./ \mathrm{ml}\right)$ by dipping up to five seconds. The treated insects were placed on filter paper to absorb the extra liquid. After treatment insects were transferred into individual petri dishes and provided with clean and sterilized wheat grains as food. The control groups of insects were treated with Tween 80 solution and reared under the same given conditions as described earlier. Five treatments with control were used and these treatments/concentrations were repeated four times. The data for fungal treatment was recorded at daily basis for seven days and cadavers were shifted to petri dishes with wet filter paper for fungal sporulation. The data regarding toxicity of different concentrations of two insect pathogenic fungi on $T$. castaneum was corrected by using Abbott's formula (Abbott, 1925) and data were statistically analysed by using SAS (SAS, 2002). The means for corrected mortality of adults and immatures of treated insects by application of B. bassiana and I. fumosorosea were separated by Duncan's Multiple Range Test (DMRT).

\section{Results and Discussion}

The pathogenicity of $B$. bassiana was evaluated against adults of $T$. castaneum which displayed the mortality on the third day after infection. Mortality of $T$. castaneum infected with $B$. bassiana was concentration dependent which augmented with the application of higher concentrations. Minimum $12.5 \%$ and maximum $32.5 \%$ mortality was noted on $7^{\text {th }}$ day after the application with $2 \times 10^{8}$ and $5 \times 10^{8}$ spores/ml fungus, respectively (Figure 1 ). The results showed that $B$. bassiana at these concentrations was not effective to control $T$. castaneum. On the other hand, the virulence of $I$. fumosorosea was evaluated against T. castaneum adults which showed similar results as that of treatment with $B$. bassiana. Cumulative mean percent mortality of $T$. castaneum treated with I. fumosorosea amplified with the increase in concentrations. Minimum i.e., $7.5 \%$ mortality and maximum $22.5 \%$ mortality was noted on $7^{\text {th }}$ day after infection with concentrations $2 \times 10^{8}$ and $5 \times 10^{8}$ of $I$. fumosorosea, correspondingly (Figure 2). The infection with $B$. bassiana on $2^{\text {nd }}$ instar immatures exhibited mortality on the third day at concentrations of $4 \times 10^{8}$ and $5 \times 10^{8}$ spores $/ \mathrm{ml}$. Minimum $2.5 \%$ mortality on $5^{\text {th }}$ day and maximum mortality percentage i.e., 80.0 was noted on $7^{\text {th }}$ day after the infection with $2 \times 10^{8}$ and $5 \times 10^{8}$ spores/ml of B. bassiana, correspondingly (Figure 3 ). The $\mathrm{LC}_{50}$ values on the $2^{\text {nd }}$ instar $T$. castaneum were $4.36 \times 10^{8}$ and $3.31 \times 10^{8}$ spores $/ \mathrm{ml}$ on $6^{\text {th }}$ and $7^{\text {th }}$ day post infection (Table 1). Contrary, lethal time $\mathrm{LT}_{50}$ was 6.41 and 5.09 days after the application of $4 \times 10^{8}$ and $5 \times 10^{8}$ spores $/ \mathrm{ml}$ (Table 2).

Table 1. Lethal doses $\left(\mathrm{LD}_{50}\right.$ and $\mathrm{LD}_{90}$ values of Beauveria bassiana and Isaria fumosorosea against $2^{\text {nd }}$ instar grubs of Tribolium castaneum

\begin{tabular}{cc|cccc}
\hline Fungi & Days & LD 50 & F.D (Fiducial limits) & Slope & D.F \\
\hline \multirow{2}{*}{ Beauveria bassiana } & $6^{\text {th }}$ & $4.36 \times 10^{8}$ & $3.68 \times 10^{8}-5.18 \times 10^{8}$ & $4.88 \pm 1.27$ & 2 \\
& $7^{\text {th }}$ & $3.31 \times 10^{8}$ & $2.75 \times 10^{8}-3.99 \times 10^{8}$ & $3.57 \pm 1.03$ & 2 \\
\hline Isaria fumosorosea & $7^{\text {th }}$ & $4.18 \times 10^{8}$ & $3.26 \times 10^{8}-5.38 \times 10^{8}$ & $3.10 \pm 1.05$ & 2 \\
\hline
\end{tabular}

Table 2. Lethal times $\left(\mathrm{LT}_{50}\right.$ and $\mathrm{LT}_{90}$ ) values of Beauveria bassiana and Isaria fumosorosea against $2^{\text {nd }}$ instar grubs of Tribolium castaneum

\begin{tabular}{cc|cccc}
\hline Fungi & Concentration & LT $_{50}$ & F.D (Fiducial limits) & Slope & D.F \\
\hline \multirow{2}{*}{ Beauveria bassiana } & $4 \times 10^{8}$ & 6.41 & $5.18-7.93$ & $3.57 \pm 0.81$ & 5 \\
& $5 \times 10^{8}$ & 5.09 & $4.42-5.86$ & $4.26 \pm 0.80$ & 5 \\
\hline \multirow{2}{*}{ Isaria fumosorosea } & $4 \times 10^{8}$ & 7.50 & $5.88-9.69$ & $3.96 \pm 1.02$ & 5 \\
& $5 \times 10^{8}$ & 6.58 & $5.41-8.00$ & $4.16 \pm 0.96$ & 5 \\
\hline
\end{tabular}




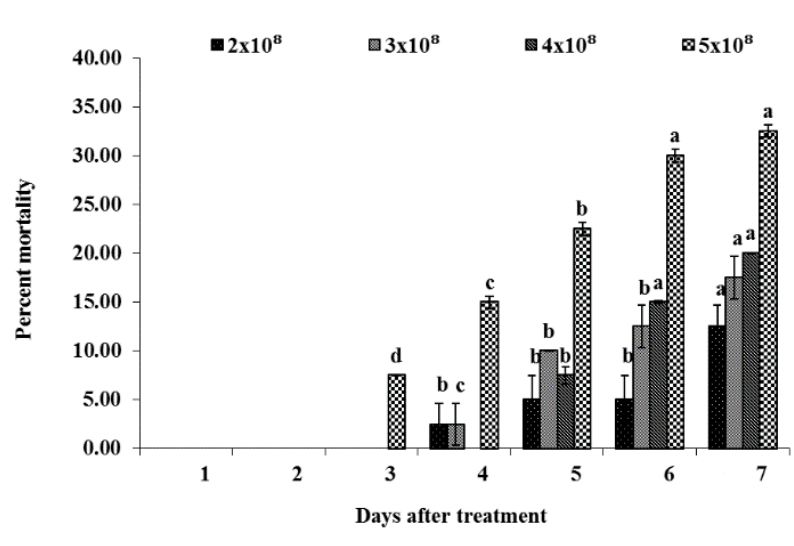

Figure 1. Percent mortality of Tribolium castaneum adults after infection with Beauveria bassiana.

(For each day the similar alphabets are not statistically different $(\mathrm{P}<0.05)$ according to DMRT)

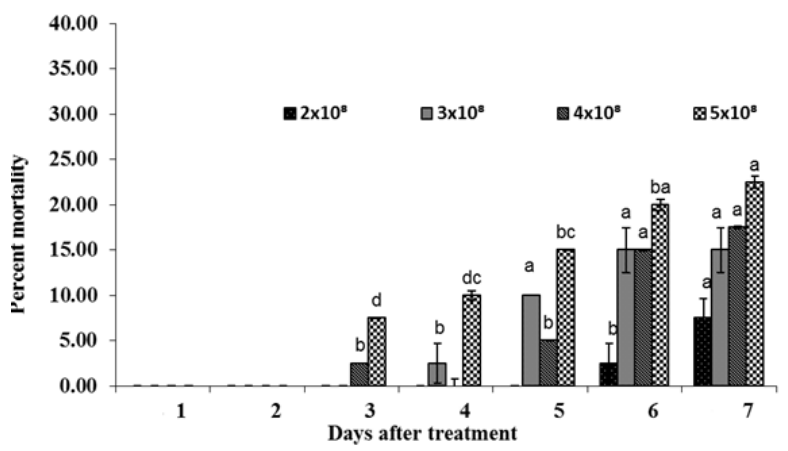

Figure 2. Percent mortality of Tribolium castaneum adults after infection with Isaria fumosorosea.

(For each day the similar alphabets are not statistically different $(\mathrm{P}<0.05)$ according to DMRT $)$

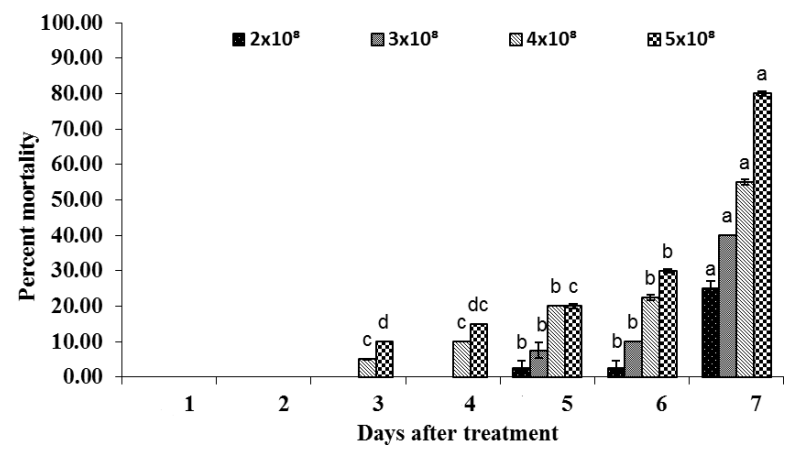

Figure 3. Percent mortality of Tribolium castaneum immatures after infection with Beauveria bassiana. (For each day the similar alphabets are not statistically different $(\mathrm{P}<0.05)$ according to DMRT)

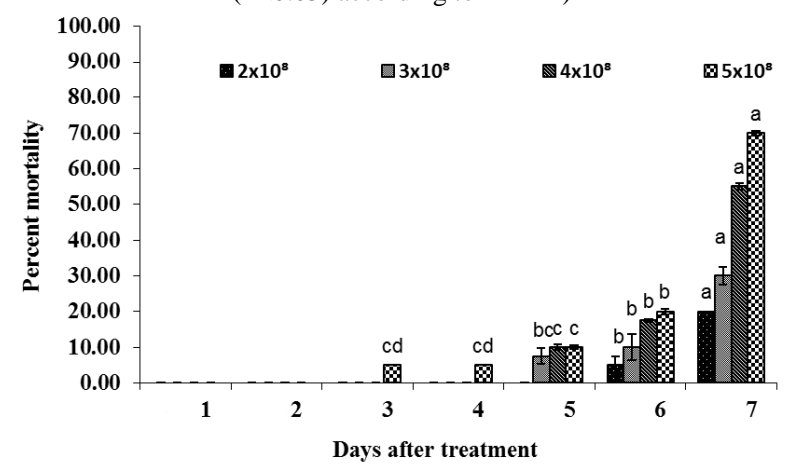

Figure 4. Percent mortality of Tribolium castaneum immatures after infection with Isaria fumosorosea. (For each day the similar alphabets are not statistically different $(\mathrm{P}<0.05)$ according to DMRT)
The application of I. fumosorosea on $2^{\text {nd }}$ instar exhibited mortality on the third day after infection with $5 \times 10^{8}$ spores $/ \mathrm{ml}$ concentration. Over all mean percent mortality of $2^{\text {nd }}$ instar grubs of $T$. castaneum positively correlated with the increase of dose of I. fumosorosea. Minimum 5.0 and maximum $70.0 \%$ mortality was noted on $6^{\text {th }}$ and $7^{\text {th }}$ day after infection with $2 \times 10^{8}$ and $5 \times 10^{8}$ spores/ml (Figure 4). The I. fumosorosea $\mathrm{LC}_{50}$ on the $2^{\text {nd }}$ instar T. castaneum was $4.18 \times 10^{8}$ on $7^{\text {th }}$ day (Table 1$)$. On the other hand, $\mathrm{LT}_{50}$ was 7.5 days after treatment with $4 \times 10^{8}$ spores $/ \mathrm{ml}$ concentration. Conversely, it was decreased to 6.58 days after infection with $5 \times 10^{8}$ spores $/ \mathrm{ml}$ concentration (Table 2).

Our results clearly showed that with increasing concentration of insect pathogenic fungi produces higher mortalities in $2^{\text {nd }}$ instars grubs of $T$. castaneum on wheat which is also supported with the results of Athanassiou and Steenberg (2007), who applied B. bassiana with diatomaceous earth against Sitophilus granaries. In other study Michalaki et al. (2006), checked M. anisopliae against $T$. confusum and results showed that mortality was increased by using high dose rate up to $8 \times 10^{10}$ conidia $/ \mathrm{kg}$ with wheat also supports our results which showed mortality up to 70 and $80 \%$ in $2^{\text {nd }}$ instars grubs by using concentration of $5 \times 10^{8}$ of I. fumosorosea and B. bassiana, respectively.

Our findings explained that the mortality of $T$. castaneum was concentration dependent and it augmented as concentrations increased but not very high in adults of this insect. The findings of current study are in conformity with the results of Akbar et al. (2004), who showed that $T$. castaneum displayed insufficient infectivity to B. bassiana. This supports our results on adults where maximum 32.5 and $22.5 \%$ mortality was recorded on adults of $T$. castaneum by using concentrations of B. bassiana and I. fumosorosea.

Fungi have the potency to be used on commercial basis as microbial control as friendly pest mangement (Throne and Lord, 2004). The findings of the current experiment clearly depicted that mortality was low up to 32.5 and $22.5 \%$ by using higher concentrations $5 \times 10^{8}$ of $B$. bassiana and $I$. fumosorosea, respectively as reported by Rice and Cogburn 1999, Padin et al. 2002 on the adults of T. castaneum. Nevertheless, still lower concentration of $B$. bassiana has revealed to have a reasonably improved control on other insects such as $R$. dominica etc. (Lord 2001).

Conclusion: The study showed the potential of insect pathogenic fungi for the management of stored grain insect pests. Both insect pathogenic fungi have potential against T. castaneum and should be mass produced and used on commercial scale.

\section{References}

Adane K, Moore D, Archer SA. 1996. Preliminary studies on the use of Beauveria bassiana to control Sitophilus Zeamais (Coleoptera: Curculionidae) in the laboratory. J. Stored Prod. Res. 32: 105-113.

Akbar W, Lord JC, Nechols JR, Howard RW. 2004. Diatomaceous Earth Increases the Efficacy of Beauveria bassiana against Tribolium castaneum Larvae and Increase Conidia Attachment. J. Econ. Entomol. 97: 273-280.

Arthur FH. 1992. Residual efficacy of chlorpyrifos-methyl, bioresmethrin and chlorpyrifos-methyl resmethrin for controlling lesser grain borers (Coleoptera: Bostrichidae), Rice weevil (Coleoptera: Curculionidae) and red flour beetle (Coleoptera: Tenebrionidae) in stored wheat. J. Econ. Entomol. 85, 570-576. 
Athanassiou CG, Steenberg T. 2007. Insecticidal effect of Beauveria bassiana (Balsamo) Vuillemin (Ascomycota: Hypocreales) in combination with three diatomaceous earth formulations against Sitophilus granarius (L.) (Coleoptera: Curculionidae). Biol. Control, 40: 411-416.

Bakhtawar M, Qamar S, Syed MZ, Shafqat S, Tariq A, Nida I, Waqar J, Muhammad NQ, Muhammad RA. 2016. Role of storage facilities for insect pest control strategies in Punjab, Pakistan. J. Stored Prod. Postharvest Res. 4(4): 55-60.

Batta YA. 2004. Control of the rice weevil Sitophilus oryzae (L.) (Coleoptera: Curculionidae) with various formulations of Metarhizium anisopliae. Crop Prot., 23: 103-108.

Batta YA. 2005. Control of lesser grain borer Rhyzopertha dominica (F.) (Coleoptera: Bostrychidae) by treatment with residual formulation of Metarhizium anisopliae (Metschnikoff) Sorokin (Deutromycotina: Hyphomycetes). J. Stored Prod. Res. 41: 221-229.

Beeman RW, Wright VF. 1990. Monitoring of resistance to chlorpyrifos-methyl, pirimiphos-methyl and malathion in Kansas populations of stored-product insects. Kansas Entomol. Soc. 63: 385-392.

Bourassa C, Vincent C, Lomer CJ, Borgemeister C, Mauffette Y. 2001. Effects of entomopathogenic Hyphomycetes against the Larger Grain Borer, Prostephanus truncatus (Horn) (Coleoptera: Bostrichidae), and its predator, Teretriosoma nigrescens Lewis (Coleoptera: Histeridae). J. Invertebr. Pathol. 77: 75-77.

Cogburn RR. 1980. Insect pests of stored rice. In: Bor Shiun, Luh (Ed.), Rice: Production and Utilisation. AVI Publications, Westport, USA, pp. 289-310.

Cox PD, Wilkin DR. 1996. The Potential Use of Biological Control of Pests in Stored Grain. Research Review 36. London: Home-Grown Cereals Authority.

Dal-Bello G, Padin S, Llopez-lastra C, Fabrizio M. 2001. Laboratory evaluation of chemical biological control of the Rice Weevil (Sitophilus oryzae L.) in stored grains. J. Stored Prod. Res. 37 (1): 77-84.

Haliscak JP, Beeman RW. 1983. Status of malathion resistance in five genera of beetles infesting farm-stored corn, wheat, and oats in the United States. J. Econ. Entomol. 76: 717-722.

Hidalgo E, Moore D, Le Patourel G. 1998. The effect of different formulations of Beauveria bassiana on Sitophilus zeamais in stored maize. J. Stored Prod. Res. 34: 171-179.

Kljajić P, Andrić G, Adamović M, Bodroža-Solarov M, Marković M, Perić I. 2010. Laboratory assessment of insecticidal effectiveness of natural zeolite and diatomaceous earth formulations against three stored-product beetle pests. J. Stored Prod. Res. 46(1): 1-6.

Lord JC. 2001. Desiccant dusts synergize the effect of Beauveria bassiana (Hyphomycetes: Moniliales) on stored-grain beetles. J. Econ. Entomol. 94: 367-372.

Mahdi Sh. HA, Rahman MDK. 2008. Insecticidal effect of some spices on Callosobruchus maculatus (Fabricius) in black gram seeds. Rajshahi Univ. Zool. Soc. 27: 47-50.

Michalaki MP, Athanassiou CG, Kavallieratos NG, Batta YA, Balotis GN. 2006. Effectiveness of Metarhizium anisopliae (Metschnikoff) Sorokin applied alone or in combination with diatomaceous earth against Tribolium confusum $\mathrm{Du} \mathrm{Val}$ Larvaelarvae: influence of temperature, relative humidity and type of commodity. Crop Prot. 25: 418-428.

Moino A, Alves SB, Pereira RM. 1998. Efficacy of Beauveria bassiana (Balsamo) Vuillemin isolates for control of storedgrain Pests. J. App. Entomol. 122: 301-305.

Moore D, Lord JC, Smith SM. 2000. Pathogens. In: Subramanyam, BhB.H., Hagstrum, D.W. (eds) Alternatives to Pesticides in Stored-Product IPM, Kluwer pp. 193-227.

Murad AM, Laumann RA, Lima T.de.A, Sarmento RBC, Noronha EF, Rocha TL, Valadares-Inglis MC, Franco OL. 2006. Screening of entomopathogenic Metarhizium anisopliae isolates and proteomic analysis of secretion synthesized in response to Cowpea weevil (Callosobruchus maculatus) exoskeleton. Comp. Biochem. Physiol. Part C: Toxicol. Pharmacol. 142: 365-370.
Norman KNT. 2000. The persistence of methyl bromide residues in rice, dried fruit, seeds and nuts following laboratory fumigation. Pest Manag. Sci., 56: 154-158.

Padin S, Dal Bello G, Fabrizio M. 2002. Grain losses caused by Tribolium castaneum, Sitophilus oryzae and Acanthoscelides obtectus in stored durum wheat and beans treated with Beauveria bassiana. J. Stored Prod. Res. 38: 69-74.

Pheloung P, Macbeth F. 2002. Export inspection: adding value to Australia's grain. In: Wright, E.J., Banks, H.J., Highley, E. (Eds.), Stored Grain in Australia 2000. Proceedings of the Australian Postharvest Technical Conference, Adelaide, 1-4 August 2000. CSIRO Stored Grain Research Laboratory, Canberra, Australia, pp. 15-17.

Phillips TW, Throne JE. 2010. Biorational approaches to managing stored-product insects. Annu. Rev. Entomol., 55: 375-397.

Rajashekar Y, Bakthavatsalam N, Shivanandappa T. 2012. Review article, botanicals as grain protectants, Hindawi Publishing Corporation, Psyche. Vol. 2012, pp 13, doi:10.1155/2012/646740.

Rajendran S. 2002. Postharvest pest losses. In: Pimentel, D. (Ed.), Encyclopedia of Pest Management. Marcel Dekker, Inc., New York, pp. 654-656.

Rice WC, Cogburn RR. 1999. Activity of entomopathogenic fungus Beauveria bassiana (Deuteromycota: Hyphomycetes) against three coleopteran pests of stored grain. J. Econ. Entomol. 92: 691-694.

Salem SA, Abou-Ela RG, Matter MM, El-Kholy MY. 2007. Entomocidal effect of Brassica napus extracts on two store pests, Sitophilus oryzae (L.) and Rhizopertha dominica (Fab.) (Coleoptera). J. Appl. Sci. Res. 3: 317-322.

Singh RKP, Satapathy KK. 2003. Zero Energy Cool Chamber: a low cost storage structure. J. North Eastern Council. 23: 2730

Smith SM, Oduor GI, Moore D. 1998. Preliminary investigations into the potential of entomopathogenic fungi for the control of pests of stored maize. In: Smith, PH, (ed). Insect Pathogens and Insect Parasitic Nematodes. Bulletin OILB/SROP, 21: 53- 60.

Stathers T. 2002. Entomopathogenic fungi in grain storage any lessons for Europe from Elsewhere? In: Zdarkova, E., Lukas, J., Hubert, J. (Eds.), Proceedings of the $2^{\text {nd }}$ Meeting of WG 4 of COST Action 842, Prague, pp. 100-109.

Talukder FA. 2006. Plant products as potential stored-product insect management agents- A mini review. J. Agric. Sci. 18(1): 17-32.

Udo IO. 2005. Evaluation of the potential of some local spices as stored grain protectants against the maize weevil Sitophilus zeamais Mots (Coleoptera: Curculionidae). J. App. Sci. Environ. Manag. 9: 165-168.

Wakefield M, Cox PD, Wildey KB, Price NR, Moore D, Bell DA. 2002. The use of entomopathogenic fungi for stored product insect and mite control- further progress in the Mycopest Project. In: Zdarkova E, Lukas J, Hubert J (eds) Proceedings of the Second Meeting of WG-4 of COST Action 842 Prague,30-31, pp. 110-115.

Wakil W, Ashfaq M, Ghazanfar MU, Riasat T. 2010. Susceptibility of stored-product insects to enhanced diatomaceous earth. J. Stored Prod. Res. 46(4): 248-249.

White NDG. 1995. Insects, mites and insecticides in stored-grain ecosystems. In: Jayas, P., White, N.D.G., Muir, W.E. (Eds.), Stored- Grain Ecosystems. Marcel-Dekker, New York, pp. 123-167.

Zettler JL, Cuperus G. 1990. Pesticide resistance in Tribolium castaneum (Coleoptera: Tenebrionidae) and Rhyzopertha dominica (Coleoptera: Bostrichidae) in Wheat. J. Econ. Entomol. 83, 1677-1681. 